\title{
Rat Bioassay for Evaluation of Protein Quality of Soy-Fortified Complementary Foods
}

\author{
Elijah H. Kamau ${ }^{1}$, Charlotte A. Serrem ${ }^{1} \&$ Florence W. Wamunga ${ }^{1}$ \\ ${ }^{1}$ Department of Family and Consumer Sciences, University of Eldoret, Kenya \\ Correspondence: Elijah H. Kamau, Department of Family and Consumer Sciences, University of Eldoret, Kenya. \\ Tel: 254-728-501-215. E-mail: ekellyne@gmail.com
}

Received: August 5, 2017

Accepted: September 6, $2017 \quad$ Online Published: October 12, 2017

doi:10.5539/jfr.v6n6p35

URL: https://doi.org/10.5539/jfr.v6n6p35

\begin{abstract}
Compositing complementary flours with legumes of high protein quality such as soy can be effective in abating Protein Energy Malnutrition. Soy-fortified complementary flours were developed using locally available foods from Western Kenya and used to determine the fortification effect on protein nutritional quality, growth, and rehabilitation. Ten isonitrogenous diets containing $10 \%$ protein and one containing $20 \%$ protein were formulated from six foods; maize, pearl millet, finger millet, sorghum, cassava, and banana at ratios of 70:30 flour and soy with milk powder as control and fed to weanling male albino rats. Another group was fed on a protein free diet. Banana: Soy diet had significantly superior protein nutritional quality while Maize: soy had 70\% Protein Digestibility Corrected Amino Acid Score. True Protein Digestibility of the fortified diets lay within the acceptable margin for cereal: bean mixtures. Fortification with soy improved protein quality indices of flours in rats, and by extrapolation could support growth of young children if used as complementary foods.
\end{abstract}

Keywords: protein, soy, fortification, nutrition, complementary feeding

\section{Introduction}

Millions of children in the tropical, subtropical, and least developed areas of the world suffer from malnutrition with those at the complementary feeding stage being most vulnerable (Onofiok \& Nnanyelugo, 2012; Rai, Rai and Pandey, 2007). This is because their macro and micro-nutrient needs might not be sufficiently provided for in the complementary foods (Bukusuba, Isabiry \& Nampala, 2008; Joseph \& Swanson, 1993). Additionally, low nutrient density of complementary foods further accounts for under-nutrition resulting in Protein Energy Malnutrition (PEM) as well as micro-nutrient deficiencies arise (Onofiok \& Nnanyelugo, 2012; United Nations Children's Fund [UNICEF], World Health Organization [WHO] \& World Bank [WB], 2012). In Kenya, complementary feeding occurs from the age of 4-6 months (Nyaga, 2012). Although mothers might want to give their children proper complementary foods, they are incapacitated by high rates of food insecurity (United Nations Development Program [UNDP], 2012). In Western Kenya, this situation is aggravated by poverty which stands at $57.9 \%$ for rural areas and $37.9 \%$ for the urban settlers (Kenya National Bureau of Statistics [KNBS], 2009).

Formulation of foods from root and cereal staples fortified with legumes improves the protein quality and nutrient density of complementary foods for young children (Food and Agriculture Organization [FAO]/WHO, 1998). Soy bean (Glycine max L. Merr) a legume which grows well in Western Kenya, can be used to produce composite flours for preparation of acceptable and sustainable complementary foods. The leading soy-production areas in Western Kenya region include Busia, Bungoma, Teso, Butere/Mumias, Kakamega, Mt. Elgon, Lugari, and Vihiga (International Crops Research Institute for the Semi-Arid Tropics [ICRISAT], 2013). The estimated area that is potentially viable for soy production ranges from 157,000 ha to 224,000 ha (ICRISAT, 2013). While the seed system seeks to ensure that small holder farmers have access to improved seed varieties, seed bulking for the crop has been adopted in three regions of Western Kenya; Busia, Siaya, and Teso (Alliance for a Green Revolution in Africa [AGRA], 2013). The main varieties grown in western Kenya include SB-19, SB-25, SB-30 and SB-132.

The nutritive value of soy bean is unique among legumes with a high protein content of 30 to $45 \%$ compared to maize and cassava with $9.42 \%$ and 1.4\%, respectively (United States Department of Agriculture [USDA], 2012). Additionally, the indispensable amino acid profile of soy beans is comparable to the reference pattern for 
children aged 2 to 5 years (Vasconcelos et al., 2001).

Although efficacy of soy fortified complementary foods has been tried in other regions of the world using animal models, there is limited information on such trials from Western Kenya (Kure \& Wyasu, 2013). Therefore, the aim of the study was to investigate the protein quality indices of soy-fortified complementary foods from Western Kenya using a rat bioassay.

\section{Materials and Methods}

\subsection{Preparation of Flours}

Samples of the six foods commonly used in Western Kenya for complementary feeding were purchased from farmers in Western Kenya. These included; maize (Zea mays), red, high tannin sorghum (Sorghum bicolor), finger millet (Leusine carocana), pearl millet (Pennisetum glaucum), dried cassava (Manihot esculenta), and raw cooking bananas (Musa acuminata). Soybean (variety SB-19) was obtained from farmers in Siaya County. Skimmed milk powder (Miksi ${ }^{\circledR}$, Promasidor Ltd, Nairobi, Kenya) containing 30\% protein, Mineral mix and Vitamin mix (Amilyte ${ }^{\circledR}$, Ultravetis East Africa Ltd., Nairobi, Kenya), corn oil (Elianto ${ }^{\circledR}$, BIDCO Oil Refineries Ltd, Thika, Kenya) and corn starch (Zesta Corn Starch ${ }^{\circledR}$, Trufoods Ltd, Nairobi, Kenya) were also purchased from Eldoret.

Heat treatment was used to neutralize the anti-nutrient factors in soy (Riaz, 2012). The soy beans were washed, sieved, and dried in an oven at a temperature of $75^{\circ} \mathrm{C}$ for 1 hour in order to bring the moisture content down to about 10\% (Riaz, 2012). After drying, the beans underwent tempering by putting in a pre-heated oven for about 72 hours so as to stabilize the moisture content. This was followed by a second cleaning through sieving and grinding. The rest of the grains, dried bananas and cassava were milled separately using a commercial hammer mill (Powerline ${ }^{\circledR}$, BM-35, Kirloskar, India) in Eldoret town fitted with a $2.0 \mathrm{~mm}$ opening screen. The six flours were composited fortified with $30 \%$ soy flour (Kure \& Wyasu, 2013).

\subsection{Diet Formulation}

A total of eleven (11) diets were formulated. These included 6 soy fortified diets at complementary flour to soy flour ratio 70: 30, two unfortified maintenance diets comprising of pure maize flour and pure finger millet flour respectively, a protein free diet, a rehabilitation diet, and a skimmed milk powder diet. Of these, nine isonitrogenous diets, containing $10 \%$ crude protein each, were prepared from the eight sample flours and milk powder (Association of Official Analytical Chemists [AOAC], 1995). The milk powder diet was the reference or control (Baskaran, Mahadevamma, Malleshi, Jayaprakashan \& Lokesh, 2001). The tenth diet was protein free while the eleventh diet, meant for rehabilitation, was made up of finger millet with soy at a ratio of 50:50 (Table 1).

All the experimental diets were prepared by incorporating the flours and milk powder into the protein free diet at the expense of the cornstarch-sucrose mixture of 1:1 ratio to obtain the required $1000 \mathrm{~g}$ by volume. The diets also provided $1 \%$ cellulose (bran), $5 \%$ mineral and $1 \%$ vitamin fortification mixes. In the protein-free diet, corn-starch sucrose mixture replaced the test protein. The purpose of the protein-free diet was to estimate the endogenous nitrogen excretion of the rats. The rehabilitation diet was prepared with the aim of providing $20 \%$ protein for catch-up growth. In order to provide this level of proteins, finger millet flour which had the highest protein content among the study complementary foods was composited with soy flour at the ratio of 50: 50. The amount of composite flour for the diet was calculated using the formula:

$$
20 \% \text { protein content }=\frac{3.2 \times 100}{\% \mathrm{~N} \text { of sample }}
$$

The other dietary constituents for the rehabilitation diet were calculated in a similar way as for the other experimental diets. The oil content in all the ten diets was adjusted to $9 \%$ using corn oil (AOAC, 1995).

\subsection{Animals and Housing}

Forty weanling male Albino rats, four to six-week-old from the same colony, weighing 90-130 g were purchased from the University of Nairobi department of Biological Sciences. The animals were housed individually in wire-bottomed cages to allow faecal matter to drop on a base tray. The rats had exactly 12 hours of light and 12 hours of darkness in a day. Temperature was maintained at $21-25^{\circ} \mathrm{C}$ while a humidifier was used to maintain the humidity between $40-70 \%$. Animal trials were carried out in line with regulations on use of animals for research (National Research Council [NRC], 2011). 


\subsection{Experimental Design}

The growth, rehabilitation, and digestibility studies were carried out using the Completely Randomized Design (CRD). Rats were randomly assigned to the treatments based on their weights. There were ten treatments each replicated four times. The rats were the replicates while the different diets were the treatments.

Table 1. Formulation of Eleven Experimental Diets (g/kg)

\begin{tabular}{|c|c|c|c|c|c|c|c|c|c|c|c|}
\hline \multirow[b]{2}{*}{ Ingredients } & \multicolumn{11}{|c|}{ Diet Weighting } \\
\hline & Maize & $\begin{array}{l}\text { F. } \\
\text { Millet }\end{array}$ & $\begin{array}{l}\text { Cassava: } \\
\text { Soy }\end{array}$ & $\begin{array}{l}\text { Maize: } \\
\text { Soy }\end{array}$ & $\begin{array}{l}\text { Sorghum: } \\
\text { Soy }\end{array}$ & $\begin{array}{l}\text { F. } \\
\text { Millet: } \\
\text { Soy }\end{array}$ & $\begin{array}{l}\text { Banana: } \\
\text { Soy }\end{array}$ & $\begin{array}{l}\text { P. } \\
\text { Millet: } \\
\text { Soy }\end{array}$ & $\begin{array}{l}\text { Milk } \\
\text { Powder }\end{array}$ & $\begin{array}{l}\text { Protein } \\
\text { Free }\end{array}$ & $\begin{array}{l}\text { Rehab. } \\
\text { Diet }\end{array}$ \\
\hline \multicolumn{12}{|l|}{ Flours } \\
\hline Maize & 840 & 0 & 0 & 0 & 0 & 0 & 0 & 0 & 0 & 0 & 0 \\
\hline F. Millet & 0 & 807.7 & 0 & 0 & 0 & 0 & 0 & 0 & 0 & 0 & 404.55 \\
\hline Soy Flour & 0 & 0 & 0 & 0 & 0 & 0 & 0 & 0 & 0 & 0 & 404.55 \\
\hline Composites & & & & & & & & & & & 0 \\
\hline Cassava: Soy & 0 & 0 & 669.30 & 0 & 0 & 0 & 0 & 0 & 0 & 0 & 0 \\
\hline Maize: Soy & 0 & 0 & 0 & 582.38 & 0 & 0 & 0 & 0 & 0 & 0 & 0 \\
\hline $\begin{array}{l}\text { Sorghum: } \\
\text { Soy }\end{array}$ & 0 & 0 & 0 & 0 & 544.40 & 0 & 0 & 0 & 0 & 0 & 0 \\
\hline F. Millet: Soy & 0 & 0 & 0 & 0 & 0 & 497.54 & 0 & 0 & 0 & 0 & 0 \\
\hline Banana: Soy & 0 & 0 & 0 & 0 & 0 & 0 & 690 & 0 & 0 & 0 & 0 \\
\hline $\begin{array}{l}\text { P. Millet: Soy } \\
\text { Others }\end{array}$ & 0 & 0 & 0 & 0 & 0 & 0 & 0 & 548.38 & 0 & 0 & 0 \\
\hline Milk Powder & 0 & 0 & 0 & 0 & 0 & 0 & 0 & 0 & 333.32 & 0 & 0 \\
\hline Corn Oil & 90 & 90 & 90 & 90 & 90 & 90 & 90 & 90 & 90 & 90 & 90 \\
\hline Mineral Mix & 50 & 50 & 50 & 50 & 50 & 50 & 50 & 50 & 50 & 50 & 50 \\
\hline Vitamin Mix & 10 & 10 & 10 & 10 & 10 & 10 & 10 & 10 & 10 & 10 & 10 \\
\hline Bran & 10 & 10 & 10 & 10 & 10 & 10 & 10 & 10 & 10 & 10 & 10 \\
\hline Corn Starch & 0 & 16.15 & 85.35 & 128.81 & 147.80 & 171.23 & 75 & 145.81 & 253.34 & 420 & 15.45 \\
\hline Sucrose & 0 & 16.15 & 85.35 & 128.81 & 147.80 & 171.23 & 75 & 145.81 & 253.34 & 420 & 15.45 \\
\hline TOTAL & 1000 & 1000 & 1000 & 1000 & 1000 & 1000 & 1000 & 1000 & 1000 & 1000 & 1000 \\
\hline
\end{tabular}

\subsection{Growth Study}

Growth study lasted 28 days. Before the start of the experiment, the weight of the rats was taken using an electronic balance (Gebr. Bosch PE 625, Germany) and repeated on alternate days throughout the study. The first six groups were fed on cassava, maize, sorghum, finger millet, banana, and pearl millet flours fortified with soy at the ratio of 70:30. The seventh and eighth groups were fed on unfortified pure maize and finger millet diets, respectively. The ninth group was fed on two diets. First, the group was fed on the protein-free diet for 11 days. On the $12^{\text {th }}$ day of the growth study, the protein-free diet was stopped and the rehabilitation diet introduced. The tenth group, the control, was fed on the skimmed milk powder diet. Each rat received $16 \mathrm{~g}$ of food per day. Water and food were available ad libitum. The data collected from this study was used in calculating the weight gained in the duration of the study which helped in the determination of the Food Efficiency Ratio (FER), Net Protein Retention Ratio (NPRR) and Protein Efficiency Ratio (PER) (See Appendix).

\subsection{Digestibility Study}

The protein digestibility study lasted five days from day 7 - day 11 of the growth study. During this period, records for the food given to each rat per day were maintained. The food remnants were also collected at the end of the day. The difference between food allowance and food remnants was used to calculate the food consumed per rat daily. The faecal material for each rat was collected daily into polyethylene bags and stored in a refrigerator.

\subsection{Rehabilitation Study}

The rehabilitation study lasted 17 days from day 12 - day 28 of the growth study. After the digestibility tests, the experimental group which had been fed on the protein-free diet had lost weight. Since they could not be allowed to lose more than $20 \%$ of their body weight, they were put on a rehabilitation program. During this time, they continued receiving a daily food allowance of $16 \mathrm{~g} / \mathrm{rat} / \mathrm{day}$ from the finger millet: soy 50:50 ratio diet. The weights of the rats were taken on alternate days throughout the remaining period. 


\subsection{Chemical Analyses}

The faecal materials were pooled per group and sun-dried for 8 hours, then crashed using a mortar and pestle. The crude protein (N X 6.25) content of the faecal material was determined using the micro kjeldahl procedure (AOAC, 1995). Faecal nitrogen from the rats fed the protein-free diet was used to calculate the endogenous nitrogen loss. True Protein Digestibility (TPD) was computed from nitrogen intake, faecal nitrogen, and endogenous faecal nitrogen. Apparent Protein Digestibility (APD), Net Protein Retention Ratio (NPRR) and Protein Efficiency Ratio (PER), were also computed (Appendix).

\subsection{Protein Digestibility Corrected Amino Acid Score (PDCAAS)}

PDCAAS is a method used in determining the protein quality of a food based on the requirement pattern for human beings (FAO 2011). Amino acid scores for the 9 indispensable amino acids were calculated. These calculations were based on the requirement pattern for children aged 1 to 2 years.

$$
\text { Amino acid score }=\frac{\mathrm{mg} \text { of Amino Acid in } 1 \mathrm{~g} \text { test protein }}{\mathrm{mg} \text { of Amino Acid in requirement pattern }(1-2 \text { year olds })}
$$

PDCAAS $=$ True Protein Digestibility x Lysine score or limiting Amino Acid Score (FAO, 2011)

\subsection{Statistical Analyses}

All the chemical analyses were done three separate times in triplicates and presented as means and standard deviation. The chemical analyses and rat growth data were subjected to one way analysis of variance (ANOVA) and means were separated using Least Significant Difference (LSD). The statistical software used was the Statistical Analysis System (SAS) version 16.

\section{Results and Discussions}

\subsection{Effect of Soy Fortified Complementary Foods on Growth and Rehabilitation in Rats}

Protein Efficiency Ratio (PER) was as reported in Table 2. PER is one of the commonly used methods of assessing the quality of a protein (FAO, 2011). A food with a higher PER is deemed superior to a food that yields a lower PER. The significant difference in PER between the reference protein and cassava: soy diet (Table 2) could have been a function of anti-nutritional factors in cassava and soy which hindered effective utilization of the proteins (Nassar \& Sousa, 2007). As expected, low PER was recorded in the basal diet because it had no protein content. The fortified diets emerged superior to the non-fortified diets as seen by the very low PER in maize meal. This confirms that cereal and legume combinations have superior protein quality compared to the individual legumes or cereals (Joseph \& Swanson 1993). However, pure finger millet had a PER similar to the reference protein. This is possibly as a result of the high protein content in the finger millet (Stabursvik \& Heide, 1974; USDA, 2013). Most fortified diets had PER similar to the reference protein despite the protein intake for the latter being higher. This is probably due to compositing cereals with legumes which yield high protein quality (FAO/WHO, 2002). It may also be attributed to the fact that the current study used milk powder with $30 \%$ protein as the reference instead of casein which has $90 \%$ protein (Baskaran et al., 2001; Rutherford \& Maughan, 2007). The significantly high PER in the banana-soy diet could be attributed to reduced amount of phytic acid and other anti-nutritional factors to complex with the protein and other nutrients which made the protein more bioavailable (Bukusuba et al., 2008; Aremu, Osifade, Basu \& Ablaku, 2011).

FER of the diets were as shown in Table 2. FER shows the ability of a food to support growth. The cassava-soy diet had a FER significantly lower than the reference. This is possibly due to the lower protein content and quality in cassava (Nassar \& Sousa, 2007). Maintenance diet containing 100\% maize was also significantly lower than all the other diets. It has also been reported that the protein content in maize meal is not enough to support growth (Mosha \& Bennink, 2004). The banana-soy diet yielded the highest value which is consistent with other findings showing higher quality of proteins in banana-soy composite (Bukusuba et al., 2008). Similarly, bananas are specifically high in lysine (Table 4), an amino acid that is limiting in all the cereal-based diets (USDA, 2012). This is further supported by the overall higher growth of animals fed on the banana-soy diet. 
Table 2. Growth Indices for Rats Fed on Non-Fortified Flours and Soy-Fortified Composites

\begin{tabular}{lllll}
\hline & PER & NPRR & Weight Gain $(g)$ & FER \\
\cline { 2 - 5 } Flours & & & & \\
Maize & $-0.01^{\mathrm{d}} \pm 2.43$ & $-1.09^{\mathrm{a}} \pm 2.64$ & $3.83^{\mathrm{c}} \pm 1.84$ & $0.001^{\mathrm{dc}} \pm 0.24$ \\
Finger Millet & $0.83^{\mathrm{ba}} \pm 2.28$ & $-0.17^{\mathrm{a}} \pm 2.53$ & $22.36^{\mathrm{ba}} \pm 3.86$ & $0.08^{\mathrm{ba}} \pm 0.23$ \\
Composites & & & & \\
Cassava + Soy & $0.25^{\mathrm{c}} \pm 0.52$ & $-0.63^{\mathrm{a}} \pm 0.50$ & $13.03^{\mathrm{b}} \pm 1.55$ & $0.03^{\mathrm{c}} \pm 0.05$ \\
Maize + Soy & $0.90^{\mathrm{ba}} \pm 0.98$ & $0.03^{\mathrm{a}} \pm 0.98$ & $27.52^{\mathrm{a}} \pm 11.99$ & $0.09^{\mathrm{a}} \pm 0.09$ \\
Sorghum + Soy & $0.67^{\mathrm{cba}} \pm 0.62$ & $-0.22^{\mathrm{a}} \pm 0.69$ & $14.5^{\mathrm{b}} \pm 7.41$ & $0.07^{\mathrm{ba}} \pm 0.06$ \\
Finger Millet + Soy & $1.17^{\mathrm{a}} \pm 1.82$ & $0.08^{\mathrm{a}} \pm 2.39$ & $24.61^{\mathrm{a}} \pm 17.59$ & $0.12^{\mathrm{ba}} \pm 0.18$ \\
Banana + Soy & $1.46^{\mathrm{a}} \pm 0.67$ & $0.48^{\mathrm{a}} \pm 0.85$ & $32.27^{\mathrm{a}} \pm 14.36$ & $0.15^{\mathrm{a}} \pm 0.07$ \\
Pearl Millet + Soy & $0.76^{\mathrm{ba}} \pm 2.09$ & $-0.22^{\mathrm{a}} \pm 2.55$ & $13.68^{\mathrm{b}} \pm 5.91$ & $0.07^{\mathrm{ba}} \pm 0.21$ \\
Protein Free & - & - & $26.61^{\mathrm{a}} \pm 10.78$ & $-0.13^{\mathrm{d}} \pm 0.04$ \\
Milk Powder & $0.95^{\mathrm{ba}} \pm 1.29$ & $0.25^{\mathrm{a}} \pm 1.27$ & $28.41^{\mathrm{a}} \pm 2.12$ & $0.11^{\mathrm{ba}} \pm 0.13$ \\
\hline
\end{tabular}

Values are means \pm standard deviation. Values with the same superscript letters along the same column are not significantly different $(\mathrm{P}<0.05)$ as assessed by Least significant difference.

PER = Protein Efficiency Ratio

NPRR $=$ Net Protein Retention Ratio

FER $=$ Food Efficiency Ratio

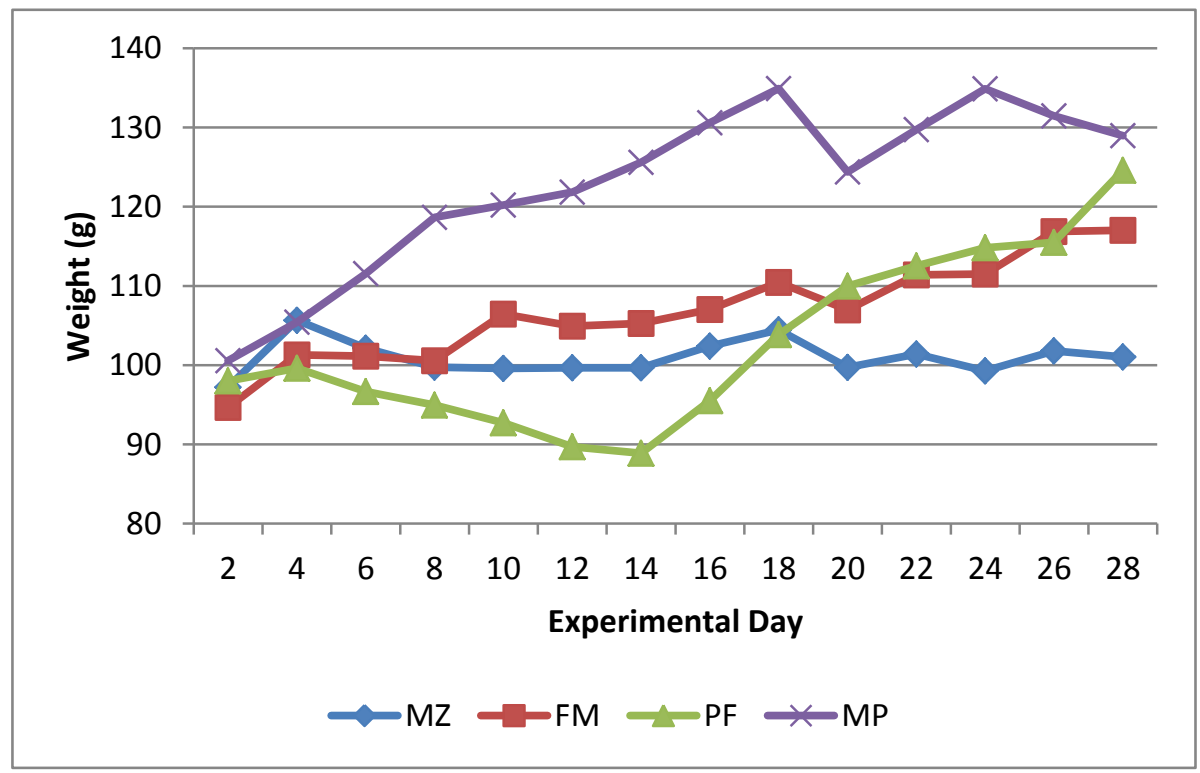

Figure 1. Growth of animals fed on maize, finger millet, pearl millet, milk powder, and protein free diet, showing rehabilitation feeding

The ultimate measure for growth was the weight gain after the 28 days of the growth study (Table 2). The banana-soy diet was the best, with the rats in the group having a total weight gain of $32.27 \mathrm{~g}$ that was $11.96 \%$ higher than the milk powder. This may be attributed to the high amino acid profile (Table 4). This is supported by reports showing that lesser protein of higher PDCAAS is better than higher quantity protein with lower PDCAAS at supporting growth (Bukusuba et al., 2008; FAO/WHO, 2002). Weight gain in the 100\% maize meal maintenance diet was a meager $3.83 \mathrm{~g}$ which was significantly lower than the corresponding maize: soy diet. Other reports also indicate that a maize meal diet cannot support growth, thus pre-disposing children to PEM (Mosha \& Vicent, 2005). Surprisingly, the 100\% finger millet maintenance diet supported growth, a fact attributable to the high protein content in the diet (Stabursvik \& Heide, 1974). Cassava: soy, pearl millet: soy and sorghum: soy diets were statistically similar to each other in supporting growth but significantly lower than the reference. This can be explained by the lower protein quality in the diets (Table 4), implying that even though these diets supported growth, they could not be equated with the reference in ensuring nourishment of the young children. The animals fed on a protein free diet lost $8.78 \mathrm{~g}$ during the first 11 days of the growth study. From day 
12 , they were introduced to the rehabilitation diet and at the end of the study there was a dramatic $35.71 \mathrm{~g}$ weight gain which was $28.25 \%$ of their original body weight and an impressive $45.10 \%$ on catch-up growth (Figure 1), asserting the potential of soy-fortified diets. These findings imply that if the fortified flours supported growth in rats, which have higher amino acid requirement than children, the growth patterns observed in this study could be extrapolated to 1-2 year old children who consume foods made using the fortified flours.

\subsection{The Protein Digestibility Study}

The food intake for the different diets is shown in Table 3. The rat group consuming the protein-free diet had the significantly lowest food intake, while the ones on milk powder and soy fortified flours were much higher. The quality and type of protein in a diet can influence food intake (Onofiok \& Nnanyelugo, 2012). Food intake is determined by the body requirements of growth and development (FAO, 2011) as well as the ability of the foods to satisfy these needs. The difference between the other diets and protein free diet with reference to food intake and protein intake could be attributed to the fact that the protein free diet did not meet the nutrient requirements of the rats. This been known to result in reduced food intake causing protein deficiency, emaciation, and death (NRC, 2011). Other workers testing the digestibility of soy-fortified sorghum biscuits revealed that food intake and protein intake was similar for the reference protein (casein), the 100\% sorghum flour and the sorghum: soy flour but all these were different from the basal diet (Serrem, de Kock, Oelofse \& Taylor, 2011). It is possible that higher intake in the protein containing diets could be a result of improved flavour of the foods due to the presence of aromatic amino acids such as histidine, phenylalanine, tryptophan, and tyrosine, thereby encouraging intake (Hui, 2006). Findings from the current study affirm earlier reports which showed that food intake and protein intake for fortified and unfortified foods were similar but higher than the basal diet (Baskaran et al., 2001). Consequently, protein quality of fortified foods can only be tested using other indices of protein quality but not the intake.

Table 3. Effect of consumption of unfortified and soy fortified flours on protein intake, output, retention and protein quality Indices

\begin{tabular}{|c|c|c|c|c|c|c|c|}
\hline & $\begin{array}{l}\text { Food } \\
\text { Intake (g) } \\
\end{array}$ & $\begin{array}{l}\text { Protein } \\
\text { Intake (g) }\end{array}$ & $\begin{array}{l}\text { Faecal } \\
\text { Output (g) }\end{array}$ & $\begin{array}{l}\text { Protein } \\
\text { Output }^{1}(\mathrm{~g})\end{array}$ & $\begin{array}{c}\text { Protein } \\
\text { Retention (g) }\end{array}$ & APD (\%) & TPD (\%) \\
\hline \multicolumn{8}{|l|}{ Flours } \\
\hline Maize & $50.72^{\mathrm{bac}} \pm 8.66$ & $5.07^{\mathrm{a}} \pm 1.15$ & $2.63^{\mathrm{c}} \pm 0.32$ & $0.23^{\mathrm{e}} \pm 0.03$ & $4.84^{\mathrm{ba}} \pm 0.12$ & $97.57^{\mathrm{a}} \pm 7.76$ & $98.72^{\mathrm{a}} \pm 2.94$ \\
\hline Finger Millet & $52.70^{\mathrm{bac}} \pm 9.97$ & $5.27^{\mathrm{a}} \pm 1.68$ & $3.89^{\mathrm{bac}} \pm 1.81$ & $0.25^{\mathrm{e}} \pm 0.07$ & $5.02^{\mathrm{ba}} \pm 0.62$ & $96.54^{\mathrm{a}} \pm 6.67$ & $97.61^{\mathrm{a}} \pm 3.24$ \\
\hline \multicolumn{8}{|l|}{ Composites } \\
\hline Cassava + Soy & $59.43^{\mathrm{ba}} \pm 3.60$ & $5.94^{\mathrm{a}} \pm 0.36$ & $3.33^{\mathrm{bc}} \pm 0.85$ & $0.74^{\mathrm{ba}} \pm 0.24$ & $5.20^{\mathrm{ba}} \pm 0.40$ & $93.05^{\mathrm{cba}} \pm 6.67$ & $94.03^{\mathrm{dcb}} \pm 6.38$ \\
\hline Maize + Soy & $60.58^{\mathrm{ba}} \pm 4.68$ & $6.06^{\mathrm{a}} \pm 0.47$ & $3.87^{\mathrm{bac}} \pm 0.71$ & $0.51^{\mathrm{dc}} \pm 0.11$ & $5.55^{\mathrm{ba}} \pm 0.49$ & $94.63^{\mathrm{ba}} \pm 4.46$ & $95.59^{\mathrm{ba}} \pm 3.62$ \\
\hline Sorghum + Soy & $58.69^{\mathrm{ba}} \pm 6.49$ & $5.87^{\mathrm{a}} \pm 0.65$ & $5.33^{\mathrm{a}} \pm 1.07$ & $0.78^{\mathrm{a}} \pm 0.07$ & $5.09^{\mathrm{ba}} \pm 0.64$ & $87.82^{\mathrm{c}} \pm 5.98$ & $88.81^{\mathrm{d}} \pm 4.55$ \\
\hline F. Millet + Soy & $47.79^{\mathrm{bc}} \pm 7.02$ & $4.78^{\mathrm{a}} \pm 1.80$ & $3.24^{\mathrm{bc}} \pm 1.64$ & $0.49^{\mathrm{bc}} \pm 0.27$ & $4.27^{\mathrm{ba}} \pm 0.54$ & $92.95^{\mathrm{cba}} \pm 3.82$ & $94.14^{\mathrm{cb}} \pm 5.39$ \\
\hline Banana + Soy & $53.36^{\mathrm{bac}} \pm 4.78$ & $5.34^{\mathrm{a}} \pm 1.02$ & $4.55^{\mathrm{ba}} \pm 1.61$ & $0.56^{\mathrm{bc}} \pm 0.13$ & $4.78^{\mathrm{ba}} \pm 0.99$ & $91.05^{\mathrm{c}} \pm 9.02$ & $92.15^{\mathrm{dc}} \pm 6.62$ \\
\hline P. Millet + Soy & $53.51^{\mathrm{bac}} \pm 7.20$ & $5.35^{\mathrm{a}} \pm 1.77$ & $4.39^{\mathrm{ba}} \pm 1.37$ & $0.39^{\mathrm{de}} \pm 0.12$ & $4.96^{\mathrm{ba}} \pm 0.65$ & $94.02^{\mathrm{ba}} \pm 3.21$ & $95.07^{\mathrm{cba}} \pm 8.78$ \\
\hline Protein Free & $39.99^{c} \pm 2.92$ & - & $0.62^{\mathrm{d}} \pm 0.18$ & - & - & - & - \\
\hline Milk Powder & $65.17^{\mathrm{a}} \pm 1.66$ & $65.17^{\mathrm{a}} \pm 1.66$ & $2.28^{\mathrm{dc}} \pm 0.47$ & $0.40^{\mathrm{de}} \pm 0.05$ & $6.12^{\mathrm{a}} \pm 0.92$ & $93.60^{\mathrm{ba}} \pm 3.73$ & $96.27^{\mathrm{ba}} \pm 1.37$ \\
\hline
\end{tabular}

Values are means \pm standard deviation. Values with the same superscript letters along the same column are not significantly different $(\mathrm{P}<0.05)$ as assessed by Least significant difference.

APD = Apparent protein Digestibility

$\mathrm{TPD}=$ True Protein Digestibility

${ }^{1}$ Faecal protein from the diet itself attained by subtracting the endogenous protein (in the protein free diet) from all the other diet

Faecal bulk during the five days of the digestibility study varied among groups (Table 3). Of all the fortified flours, only sorghum-soy, banana-soy, and pearl millet-soy were significantly higher than the milk powder protein with values that were $133.77 \%, 99.56 \%$, and $92.54 \%$ higher, respectively. Sorghum: soy and pearl millet: soy diets had the highest output of faecal volume. High faecal output is an indicator of reduced digestibility. It is possible that the presence of phytates, tannins and soy anti-nutritional factors complexed with nutrients and reduced their digestibility (Aremu et al., 2011). Other studies revealed that the sorghum proteins, kaffirins, which are less digestible made the sorghum diet have a $57.14 \%$ higher faecal protein than casein (Hui, 2006). The high faecal output in banana: soy diet, similarly, could have resulted from the low digestibility of the diet (Table 3). Nevertheless, the digestibility levels in the current study are higher than the range of legume containing diets reported at 79-85\% (Sarwar, Peace, Botting \& Brule, 1989). Therefore, this lower digestibility probably did not 
have a negative effect on the protein quality in the banana: soy diet (Bukusuba et al., 2008) as seen in the higher growth rate (Table 2 ) and higher amino acid profile (Table 4 ).

The protein output for the different diets is also indicated on Table 3. The values for the nine diets were obtained by subtracting the endogenous nitrogen excretion of the protein free diet from the total protein output of each diet. The maintenance diet comprising $100 \%$ maize flour had the lowest protein output $(0.23 \mathrm{~g})$ while sorghum-soy had the highest $(0.78 \mathrm{~g})$. Sorghum: soy had an output that was $95 \%$ higher than the milk powder. The protein output for the $100 \%$ maize meal and $100 \%$ finger millet meal maintenance diets was significantly lower than and different from the corresponding fortified diets $54.90 \%$ and $48.98 \%$, respectively. Protein retention was similar across the diets but the control had the highest value $(6.12 \mathrm{~g})$, though this was not statistically significant. The soy-fortified diets had higher nitrogen excretion compared to the reference protein. It was also notable that the faecal nitrogen of the maintenance diets was lower than that of the fortified diets. This could be explained by the fact that the cereals have lower protein content (FAO/WHO, 2002). Therefore, individuals feeding on such diets would have to retain as much of the proteins as possible. This could also be due to the fact that legumes might support microbial activities in the digestive tract (Wu et al., 1995). Other workers concluded that high microbial activity in the intestines which utilized the indigestible carbohydrates and protein from beans as the substrates increases nitrogen excretion (Wu et al., 1995). This makes many parents avoid feeding beans to their children for fear of poor protein utilization (Onofiok \& Nnanyelugo, 2012). Though the protein output in the soy-fortified diets in the current study was higher than the non-fortified diets, it is worth noting that the output was lower $(7.35-13.39 \%)$ compared to the $36-48.3 \%$ output recorded by other researchers working with kidney beans (Wu et al., 1995). This could mean that soy-bean is a good choice for fortification of complementary foods.

The APD of the diets ranged from $87.82 \%$ in sorghum-soy to $97.57 \%$ in the maize diet. This denotes a difference of $11.10 \%$. Of the fortified complementary flours, sorghum: soy $(87.82 \%)$ and banana: soy $(91.05 \%)$ were statistically similar but significantly different from the control protein. The TPD of the diets is also indicated in Table 3. Maize meal had the highest value $(98.72 \%)$ while sorghum had the lowest value $(88.81 \%)$. There was a difference of $11.16 \%$ between the highest and the lowest values. Sorghum: soy and banana: soy $(92.15 \%)$ were significantly different from the control protein $(96.27 \%)$ and maize: soy $(95.59 \%)$. Interestingly, the unfortified finger-millet diet had a significantly higher value (97.61\%) than the soy-fortified finger millet diet (94.14\%). Generally, fortification with soy reduced the digestibility of flours.

The digestibility of the soy containing complementary foods ranged from $88.81 \%$ to $95.59 \%$ indicating that the unfortified diets had higher digestibility compared to the soy-fortified diets. This difference could have been brought about by lower digestibility of the soy-beans established by Sarwar et al. (1989) that the range of digestibility for foods containing beans is $70-85 \%$. Mosha and Bennink (2004) concluded that complementary foods fortified with beans and sardines had a digestibility ranging from 82 to $94 \%$, a figure that is consistent with the findings of the current study.

\subsection{Protein Digestibility Corrected Amino Acid Score}

The quality of proteins is very important in supporting the growth of infants and young children and is best determined by use of PDCAAS (FAO, 2011). To further assess the protein quality of the fortified foods in terms of ability to meet the protein nutritional requirements of 1-2 year old children, the PDCAAS was calculated as shown in Table 4. Of the fortified flours, maize-soy valued highest (70\%) while sorghum-soy was the lowest (56\%). In comparison, the fortified diets had higher PDCAAS than the non-fortified diets. Maize: soy had a PDCAAS of $70 \%$ compared to $53 \%$ in pure maize meal which translates into a $32.08 \%$ increment as a result of fortification. Similarly, finger millet: soy had a PDCAAS of $64 \%$ compared to $46 \%$ in the non-fortified finger millet which shows that fortification led to a $39.13 \%$ rise in PDCAAS. Cassava: soy is the only diet that does not fulfill the amino acid requirements for the children aged 1-2 years, falling short by $37.47 \%$. Interestingly, the diet is not limiting in lysine and has a relatively high PDCAAS value when compared to the other diets. All the other diets meet the minimum amino acid requirements for children aged 1-2 years (FAO, 2011). Soy fortification also resulted in an increase in indispensable amino acids, isoleucine, leucine, lysine, tryptophan, threonine, and valine in maize. Finger millet, once fortified, also had an increase in lysine, threonine, isoleucine, and valine. This agrees with other studies on fortification of sorghum with soy which recorded an increase in levels of lysine, methionine, and tryptophan (Kure \& Wyasu, 2013). The Codex Alimentarius Commission has put the threshold for PDCAAS for complementary foods at $70 \%$ and above (FAO/WHO, 2002). Of the soy-fortified diets used in this study, only maize-soy diet reached this threshold, with banana-soy, finger millet-soy, and cassava-soy diets missing the mark by very small margins of $4.29 \%, 8.57 \%$, and $10 \%$. This is an indication that composites of the complementary flours and soy but with higher than the 70:30 ratio used in this study can help in preventing and 
managing cases of PEM. This is as seen in Figure 1 where a composite of finger millet-soy in the ratio 50:50 manifested dramatic recovery from wasting. Other workers came to a similar conclusion. For instance, a study on complementation of sorghum with soy found out that complementation in the ratio of 50:50 could yield a PDCAAS that meets the threshold for young children aged 1-2 years and 3-10 years.

Table 4. Comparison of Essential Amino Acid Profile in Diets with FAO Requirement Patterns for Children aged 1 - 2 Years $(\mathrm{g})$

\begin{tabular}{|c|c|c|c|c|c|c|c|c|c|c|}
\hline \multirow[b]{2}{*}{${ }^{1}$ Amino acid } & \multicolumn{9}{|c|}{ Protein Sources } & \multirow[t]{2}{*}{$\mathrm{FAO}^{2}$} \\
\hline & Maize & $\begin{array}{l}\text { F. } \\
\text { Millet }\end{array}$ & $\begin{array}{l}\text { Cassava: } \\
\text { Soy }\end{array}$ & $\begin{array}{l}\text { Maize: } \\
\text { Soy }\end{array}$ & $\begin{array}{l}\text { Sorghum: } \\
\text { Soy }\end{array}$ & $\begin{array}{l}\text { F. } \\
\text { Millet: } \\
\text { Soy }\end{array}$ & $\begin{array}{l}\text { Banana: } \\
\text { Soy }\end{array}$ & $\begin{array}{l}\text { P. Millet: } \\
\text { Soy }\end{array}$ & $\begin{array}{l}\text { Milk } \\
\text { Powder }\end{array}$ & \\
\hline Isoleucine & 35.79 & 43.99 & 27.19 & 38.34 & 38.90 & 44.08 & 31.27 & 42.83 & 60.51 & 31 \\
\hline Leucine & 122.66 & 142.98 & 42.40 & 108.18 & 112.42 & 122.41 & 66.00 & 111.25 & 97.95 & 63 \\
\hline Lysine & 28.14 & 24.49 & 40.89 & 37.94 & 32.65 & 35.38 & 50.35 & 31.71 & 79.31 & 52 \\
\hline${ }^{3}$ Met + Cystein & 38.96 & 46.24 & 28.19 & 35.38 & 33.85 & 40.48 & 19.03 & 35.62 & 34.32 & 26 \\
\hline${ }^{4} \mathrm{Phe}+$ Tyrosine & 89.75 & 93.12 & 46.8 & 87.49 & 79.99 & 89.85 & 61.91 & 83.10 & 69.58 & 46 \\
\hline Threonine & 37.66 & 32.92 & 26.32 & 38.27 & 37.79 & 34.95 & 29.89 & 34.33 & 45.13 & 27 \\
\hline Tryptophan & 7.07 & 15.82 & 13.76 & 8.93 & 12.79 & 15.06 & 9.77 & 11.54 & 14.10 & 7.4 \\
\hline Valine & 50.50 & 54.32 & 31.70 & 49.03 & 45.79 & 57.71 & 43.87 & 50.40 & 66.92 & 42 \\
\hline Histidine & 30.45 & 23.91 & 17.68 & 28.70 & 21.25 & 24.12 & 56.83 & 22.37 & 27.13 & 18 \\
\hline Total & 440.98 & 477.79 & 274.93 & 432.26 & 415.43 & 464.04 & 368.92 & 423.15 & 494.95 & 312.4 \\
\hline TPD (\%) & 98.72 & 97.61 & 94.03 & 95.59 & 88.81 & 94.16 & 92.15 & 95.07 & 96.27 & \\
\hline Limiting AA & Lysine & Lysine & Leucine & Lysine & Lysine & Lysine & $\mathrm{Met}+\mathrm{Cys}^{5}$ & Lysine & None & \\
\hline Limiting AA Score & 0.54 & 0.47 & 0.67 & 0.73 & 0.63 & 0.68 & 0.73 & 0.61 & 1.53 & \\
\hline${ }^{6}$ PDCAAS $(\%)$ & 53 & 46 & 63 & 70 & 56 & 64 & 67 & 0.58 & 100 & \\
\hline $\begin{array}{l}{ }^{1} \text { Indispensable amin } \\
\text { Release } 26 \text {. The Nat } \\
{ }^{2} \text { Amino acid require } \\
{ }^{3} \text { Methionine } \\
{ }^{4} \text { Phenylalanine } \\
{ }^{5} \text { Cystein } \\
{ }^{6} \mathrm{PDCAAS} \text { - protein }\end{array}$ & ent patt & $\begin{array}{l}\text { position } \\
\text { litural L } \\
\text { for chi }\end{array}$ & $\begin{array}{l}\text { foods is o } \\
\text { ary, } 2013 \text {. } \\
\text { en aged } 1-\end{array}$ & ears (FA & 2011) & $013) . \Lambda$ & nal Nutrient & atabase $f$ & Standard & ference \\
\hline
\end{tabular}

\section{Conclusions}

Compositing complementary foods with soy decreases the protein nutritional quality index of digestibility (APD) and (TPD) but increases the PDCAAS value, thereby increasing their ability to satisfy the amino acid reference pattern for children aged $1-2$ years. Thirty percent soy fortified complementary foods have a PER similar to the milk powder control and at 50\% can rehabilitate malnourished rats. Based on the PDCAAS, it appears that by extrapolation, fortified complementary foods can support growth and rehabilitate malnourished children.

\section{References}

AGRA. (2013). Legume Cultivation Booms in Western Kenya. Retrieved on $5^{\text {th }}$ Sept. 2013 from http://www.agra.org/what-we-do/legume-cultivation-booms-in-western-kenya/

A.O.A.C. (1995). Official Method of Analysis Association of Official and Analytical Chemists. Washington, DC, $12^{\text {th }}$ Edition.

Aremu, M. O., Osifade, B. G., Basu, S. K., \& Ablaku, B. E. (2011). Development and Nutritional Quality Evaluation of Kersting's Groundnut-Ogi for African Weaning Diet. American Journal of Food Technology, 6(12), 1021-1033. https://doi.org/10.3923/ajft.2011.1021.1033

Baskaran, A., Mahadevamma, N. G., Malleshi, S. G., Jayaprakashan, S. G., \& Lokesh, B. R. (2001). Biological Evaluation for Protein Quality of Supplementary Foods Based on Popped Cereals and Legumes Suitable for Feeding Rural Mothers and Children in India. Plant Foods for Human Nutrition, 56, 37-49. https://doi.org/10.1023/A:1008169011109

Bukusuba, J., Isabiry, F., \& Nampala, P. (2008). Enhancing Nutritional Density and Quality of Banana-Soy Based Complementary Diet through Substitution with Sesame. African Journal of Food, Agriculture, Nutrition, and Development, 8(1), 104-117. https://doi.org/10.4314/ajfand.v8i1.19183

FAO. (2011). Dietary Protein Quality Evaluation in Human Nutrition. FAO Food and Nutrition Paper 92: Report of an FAO Expert Consultation, Auckland, New Zealand.

FAO/WHO. (2002). Report of the Third Session of the Codex Ad Hoc Intergovernmental Task Force on Foods Derived from Biotechnology. Yokohama, Japan, 4-8 March 2002. 
FAO/WHO. (1998). Carbohydrate in Human Nutrition. Report of a Joint Expert FAO/WHO Consultation. FAO Food and Nutrition Paper 66. Food and Agriculture Organization, Rome.

Hui, Y. H. (2006). Handbook of Food Science, Technology, and Engineering (Vol. 2). Boca Raton, FL: CRC Press.

ICRISAT. (2013). Tropical Legume Farming in Kenya. Bulletin of Tropical Legumes II Project, 2013.

Joseph, E., \& Swanson, B. G. (1993). Growth and Nitrogen Retention of Rats Fed Bean (Phaseolus vulgaris) and Bean and Rice Diets. Food Research International, 26, 261-269. https://doi.org/10.1016/0963-9969(93)90029-I

Kenya National Bureau of Statistics. (2009). Kenya Demographic and Health Survey 2008-09. Nairobi, Kenya.

Kure, O. A., \& Wyasu, G. (2013).Influence of Natural Fermentation, Malt Addition, and Soya-Fortification on the Sensory and Physico-Chemical Characteristics of Ibyer-Sorghum Gruel. Advances in Applied Science Research, 4(1), 345-349.

Mosha, T. C. E., \& Bennink, M. R. (2004).Protein Quality of Drum-Processed Cereal-Bean-Sardine Composite Supplementary Foods for Preschool-Age Children. Journal of the Science of Food and Agriculture, 84, 1111-1118. https://doi.org/10.1002/jsfa.1756

Mosha, T. C. E. \& Vicent, M. M. (2004).Nutritional Value and Acceptability of Homemade Maize/Sorghum-based Weaning Mixtures Supplemented with Rojo-Bean Flour, Ground sardines and peanut paste. International Journal of Food Sciences and Nutrition, 55(4), 301-315. https://doi.org/10.1080/09637480410001225184

Nassar N. M. A., \& Sousa, M. V. (2007).Amino Acid Profile in Cassava and Its Interspecific Hybrid. Genetic and Molecular Research, 6(2), 292-297.

National Research Council Manual. (2011). Guide for the Care and Use of Laboratory Animals (8 ${ }^{\text {th }}$ ed.). Washington, D.C: The National Academies Press.

Nyaga, D. R. (2012). Breast-feeding and Weaning Practices among Rural and Urban Mothers of Embu District, Kenya. Retrieved on $27^{\text {th }}$ April 2013 from http://ir-library.ku.ac.ke/ir/handle/123456789/2286? show=full

Onofiok, N. O. \& Nnanyelugo, D. O. (2012). Weaning Foods in West Africa: Nutritional Problems and Possible Solutions. Retrieved on $3^{\text {rd }}$ July 2013 from http://Weaning\%20foods\%20in\%20West\%20Africa\%20\%20Nutritional\%20problems\%20and\%20possible $\% 20$ solutions.html

Rai, M., Rai, A., \& Pandey, S. (2007). Study of Weaning Practices of Infants in Selected Rural and Urban Communities of Azamgarh District. Indian Journal of Prevalent Social Medicine, 38(4), 123-143.

Riaz, M. N. (2006). Soybeans Processing into Ingredients. Retrieved on $25^{\text {th }}$ July 2013 from http://www.wishh.org/workshops/intl/southafrica/sept06/riaz1-sept06.pdf

Rutherford, S. M., \& Maughan, P. J. (2007). Development of a Novel Bio-Assay for Determining the Lysine Content for Foods and Feed Stuff. Nutr. Res. Rev., 20, 3-16. https://doi.org/10.1017/S0954422407739124

Sarwar, G., Peace, R. W., Botting, H. G., \& Brule, D. (1989).Digestibility of protein and amino acids in selected foods as determined by a rat balance method. Plant Food Human Nutrition, 39, 23-32. https://doi.org/10.1007/BF01092398

Serrem, C. A., de Kock, H. L., Oelofse, A., \& Taylor, J. N. R. (2011).Rat Bioassay of the Protein Nutritional Quality of Soy Fortified Sorghum Biscuits for Supplementary Feeding of School-age Children. Department of Food Science, University of Pretoria, SA. 1-26.

Stabursvik, A., \& Heide, M. (1974). Protein Content and Amino Acid Spectrum of Finger Millet [Eleusine coracana) (L.) Gaerttn.] as Influenced by Nitrogen and Sulphur Fertilizers. Plant and Soil, 41(3), 549-571. https://doi.org/10.1007/BF02185816

UNICEF, WHO, and WB. (2012). Levels and Trends in Child Malnutrition. UNICEF, New York; WHO, Geneva; The World Bank, Washington, DC; 2012.

UNDP. (2012). Africa Human Development Report 2012. Retrieved on 30 ${ }^{\text {th }}$ April 2013 from http://www.afhdr.org/the-report/

USDA. (2013). National Nutrient Database for Standard Reference Release 26.The National Agricultural Library, 2013. 
US Department of Agriculture. (2012). Oilseeds: World Markets and Trade. Retrieved on $19^{\text {th }}$ Dec. 2012 from "Growing Crush Limits India's Soy Oil Imports"

Vasconcelos, I. M., Maia, A. A. B., Siebra, E. A., Oliveira, J. T. A., Carvalho. A. F. F. U., Melo, V. M. M., Carlini, C. R., \& Castelar, L. I. (2001).Nutritional study of two Brazilian soybean (Glycine max) cultivars differing in contents of anti-nutritional and toxic proteins. Journal of Nutritional Biochemistry, 12, 55-62. https://doi.org/10.1016/S0955-2863(00)00148-0

Wu, W., Williams, P. W., Kunkel, M. E., Acton, J. C., Huang, Y., Wardlaw, F. B., \& Grimes, L. W. (1995). True Protein Digestibility and Digestibility-Corrected Amino Acid Score of Red Kidney Beans (Phaseolus vulgaris L.).J. Agric. Food Chem., 43, 1295-1298. https://doi.org/10.1021/jf00053a031

\section{Appendix A}

\section{Computation Equations}

The data collected from the experiment was used in calculating the following protein quality indices using the formulae suggested by FAO (2011):

$$
\begin{array}{cc}
\text { A1: Protein Efficiency Ratio (PER) }= & \text { g of weight gain } \\
\text { A2: Net Protein Retention Ratio }= & \begin{array}{c}
\mathrm{g} \text { of protein consumed } \\
\text { g of weight gain }+\mathrm{g} \text { of weight loss in protein free diet }
\end{array} \\
\text { A3: Food Efficiency Ratio }= & \begin{array}{c}
\mathrm{g} \text { of protein consumed } \\
\mathrm{g} \text { of weight gain }
\end{array} \\
\text { A4: Apparent Protein (N) Digestibility }(\%)=\frac{\mathrm{g} \text { of food consumed }}{\mathrm{I}-\mathrm{F} \times 100} \\
\text { A5: True Protein }(\mathrm{N}) \text { Digestibility }(\%)= & \mathrm{I} \\
\text { A6: Fecal Protein }(\%)= & \mathrm{I}-\left(\mathrm{F}-\mathrm{F}_{\mathrm{k}}\right) \times 100 \\
\mathrm{I}
\end{array}
$$

Where I = Nitrogen Intake (calculated from the diet composition)

$\mathrm{F}=$ Fecal Nitrogen Output on the experimental diets

$F_{k}=$ Fecal Nitrogen Output on a protein-free diet

\section{Copyrights}

Copyright for this article is retained by the author(s), with first publication rights granted to the journal.

This is an open-access article distributed under the terms and conditions of the Creative Commons Attribution license (http://creativecommons.org/licenses/by/3.0/). 